\title{
Validation of anthropometric models in the estimation of appendicular lean soft tissue in young athletes
}

\section{Validação de modelos antropométricos na estimação da massa isenta de gordura e osso apendicular em jovens atletas}

\author{
Pedro Pugliesi Abdalla1,2 \\ Analiza Mónica Silva ${ }^{3}$ \\ Anderson dos Santos Carvalho $0^{4,5}$ \\ Ana Claudia Rossini Venturini \\ Thiago Cândido Alves ${ }^{4}$ \\ André Pereira dos Santos ${ }^{4,6}$ \\ Dalmo Roberto Lopes Machado $0^{1,4}$
}

Abstract-Magnetic resonance imaging and computer tomography are gold standards in the measurement of muscle tissue (MT), but are expensive. Dual Energy X-Ray Absorptiometry (DXA) is also costly but safer and allows for the measurement of Appendicular Lean Soft Tissue (ALST), a strong predictor of MT. Alternatively, there are anthropometric models that predict the ALST of Portuguese athletes with low cost/risk that have not been validated in other populations. The aim of this study was to validate anthropometric Portuguese models that predict ALST in young athletes or, if the validation fails, to propose new models. The $\mathrm{ALST}_{\mathrm{DXA}}$ of 174 young athletes was determined by DXA. Two anthropometric models (ALST $_{\text {mod } 1}$ and ALST ${ }_{\text {mod }}$ ) measuring ALST among Portuguese athletes were tested. To validate the coefficient of determination, the difference (bias) and concordance correlation coefficient between predicted and actual values were computed. Finally, association between mean and difference of methods was verified. Validation failed and, for this reason, new multiple regression models were proposed and validated using PRESS statistics. The Portuguese models explained $\sim 96 \%$ of the ALST $_{\text {DXA }}$ variability. The difference between $\mathrm{ALST}_{\text {mod1 } 1}$ and ALST $\mathrm{DXA}(-0.7 \mathrm{~kg})$ was less than that found for the ALST mod2 $_{2}$ and ALST ${ }_{\text {DXA }}$ $(-2.3 \mathrm{~kg})$, with limits of agreement from 3.6 to -2.1 and from 6.1 to $-1.5 \mathrm{~kg}$, respectively.

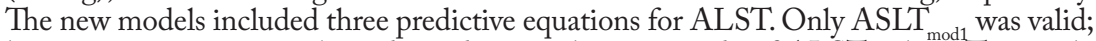
however, it was prone to bias, depending on the magnitude of ALST values. The newly proposed models present validity with greater concordance $\left(r^{2}{ }_{\text {PRESS }}=0.98\right)$, lower standard error of estimate $\left(\mathrm{SEE}_{\mathrm{PRESS}[\mathrm{kg}]}=0.91\right)$ and more homogeneous predicted extreme values.

Key words: Anthropometry; Body composition; DXA scan; Skeletal muscle; Sports.

Resumo - Ressonância magnética e tomografia computadorizada são referências para mediro tecido muscular (TM), porém apresentam custo elevado. A Absorciometria Radiológica de Dupla Energia (DXA) ésegura, embora ainda dispendiosa, permite medir a Massa Isenta de Gordura e Osso apendicular (MIGOap), forte preditor do TM. Alternativamente, existem modelos antropométricos preditivos da MIGOap de atletas portugueses com baixo custo/risco, porém sem validação para outras populaçôes. Objetivou-se validar modelos antropométricos portugueses preditivos da MIGOap em jovens atletas ou propor novos modelos, caso a validação falhe. A determinação da MIGOap de 174 jovens atletas foi realizada por DXA. Dois modelos antropométricos (MIGOap mod 1 e MIGOap mod ${ }_{\text {) }}$ de atletas portugueses foram testados para predizer MIGOap. Para validação o coeficiente de determinação, a diferença (viés) e a concordância entre valores medidos e preditos foram calculados. Finalmente, a associação entre média-e-diferença dos métodos foi calculada. A validação falhou, assim foram propostos novos modelos de regressão múltipla validados por estatistica PRESS. Os modelos portugueses explicaram $~ 96 \%$ da variabilidade da MIGOap ${ }_{D X}$. A diferença entre MIGOap, e MIGOap ${ }_{D X A}(-0,7 \mathrm{~kg})$ foi menor do que MI$\mathrm{GOap}_{\text {mod2 }}(-2,3 \mathrm{~kg})$, com limites de concordância de 3,6 a-2,1 e de 6,1 a-1,5kg, respectivamente. Os novos modelos incluíram três equações preditivas para MIGOap. Somente MIGOap madi foi válido, todavia mostrou grande tendência a vieses, conforme magnitude dos valores de MIGOap. Os novos modelos propostos mostraram validade com maior concordância $\left(r_{\text {PRESS }}^{\mathbf{2}}=0,98\right)$, menores erros de estimativa $\left(E P E_{P R E S S[\mathrm{~kg}]}=0,91\right)$ e valores preditos mais homogêneos para casos extremos.

Palavras-chave: Absorciometria de raios x; Antropometria; Composição corporal; Esportes; Músculo esquelético.
1 University of São Paulo. School of Physical Education and Sport. Postgraduate Program in Physical Education and Sport. Ribeirão Preto, SP. Brazil.

2 University of Ribeirão Preto. Nutrition Course. Ribeirão Preto, SP. Brazil.

3 University of Lisbon. Faculty of Human Motricity. Lisbon, Portugal

4 University of São Paulo. School of Nursing of Ribeirão Preto. Interunit Doctoral Program in Nursing. Ribeirão Preto, SP. Brazil.

5 Visiting scholar at University of Coastal Carolina University, USA.

6 Visiting scholar at University of Illinois at Urbana-Champaign, USA.

Received: 13 August 2017 Accepted: 20 October 2017 


\section{INTRODUCTION}

Skeletal muscular tissue (MT) is essential for athletic performance ${ }^{1,2}$, as it is the most abundant body tissue in non-obese individuals ${ }^{1,3}$. Body composition comprises five levels: I) atomic; II) molecular; III) cellular; IV) tissue; and V) total body ${ }^{3}$; MT belongs to the fourth level and corresponds to 30 to $33 \%$ of the total body mass of young people ${ }^{4}$, while in adults it corresponds to approximately $40 \%{ }^{1}$.

The use of valid and easily applicable methods to quantify the MT of young athletes is highly relevant to monitoring the effects of athletic training on one's MT structure, determining training loads in different phases and balancing training routines with dietary prescriptions, enabling the preservation of or increase in muscle mass to improve athletic performance $^{2}$. Even though MT represents a large part of one's body structure ${ }^{4}$, measuring it in live individuals is a complex task when compared to other measures, such as fat or bone tissue.

Imaging methods were developed in the 1970s to analyze MT and remain among the most used: Computed Tomography (CT), Magnetic Resonance Imaging (MRI) and Dual Energy X-ray Absorptiometry (DXA) ${ }^{5}$. The first measures using CT were performed in 1983 and in 1995 measures were performed using $\mathrm{MRI}^{5}$. Only in 1998 were both techniques validated based on the only method that involves the direct measurement of this component, the dissection of corpses ${ }^{6}$. The study showed that these methods accurately quantify MT at the tissue level (IV). Nonetheless, these methods are costly ${ }^{2}$ and difficult to apply, while CT exposes individuals to radiation, which prevents applying it repetitively ${ }^{7}$.

A less costly and more accessible alternative method, when compared to the previous ones, is $\mathrm{DXA}^{2}$. It is considered safer because it involves a minimum of radiation ${ }^{8}$ and is thus appropriate to measure the body composition of children and adolescents ${ }^{9}$. Even though DXA only makes measurements at level $\mathrm{II}^{3}$, it is possible to isolate body regions for analysis, such as the upper limbs, lean mass of the measurement of bone and fat mass called Lean soft tissue (LST) ${ }^{2}$. Appendicular LST (ALST), that is, the sum of the LST of the upper and lower limbs, is equivalent to almost all MT (level IV) in this region, with the exception of a small amount of connective tissues and skin ${ }^{2}$. Additionally, the MT that is present in the both upper and lower limbs represent approximately $75 \%$ of MT in adults ${ }^{10}$.

Based on these proportions, comparisons ${ }^{11}$ were performed and models were proposed to estimate MT with ALST measures for adults ${ }^{12}$ and children and adolescents using $\mathrm{MRI}^{4}$. These models included ALST, age and sex as independent variables and explained $96 \%$ of the variability in reference values. Additionally, they were validated in the study's sub-sample with very high correlation ( $r=0.96$ to 0.97 ), no statistically significant differences and good concordance between predicted and actual measurements. The models proposed for adults ${ }^{12}$ were valid for children and mature adolescents ${ }^{13}$, however, they overestimated the measurements of pre-pubertal 
and pubertal individuals, with a mean difference of $0.5 \mathrm{~kg}^{4}$. Therefore, three specific models were proposed for pre-pubertal and pubertal boys $(n=36)$ and girls $(\mathrm{n}=29)$. The MT measures were taken using MRI and ALST was measured using DXA. The independent variables were: ALST, body mass, height and interaction between ALST/height, explaining from 98\% to $99 \%$ of the variability of the reference method's values ${ }^{4}$. Nonetheless, even though DXA is safe and appropriate for the young population, it is still an expensive method and cannot be recurrently used in practice ${ }^{2}$.

Anthropometry, on the other hand, is a highly applicable method in the measurement of MT, given its low cost and accuracy, as long as a minimum amount of training is provided ${ }^{2}$. Models using anthropometry were proposed to predict MT among the elderly ${ }^{14,15}$ and adult individuals ${ }^{7}$ using the dissection of corpses and MRI, respectively, with proven validity $^{16,17}$. Only one study was found that proposes anthropometric models to predict ALST in athletic children and adolescents ${ }^{2}$, using data from Portuguese young individuals (176 boys and 92 girls). Even though the authors performed cross validation and obtained good results, the validity of these methods in other populations has not been tested. Specifically, there are anthropometric differences with statistical significance between Brazilian and Portuguese young individuals ${ }^{18}$, specifically height, an independent variable that is necessary to predict ALST in the models proposed. Therefore, this study's objectives included: 1) validate Portuguese anthropometric models to predict ALST in Brazilian young male athletes; and, if validation fails, 2) propose new models.

\section{METHODOLOGICAL PROCEDURES}

\section{Study's design}

This cross-sectional observational study addressed young Brazilian individuals who took part in sports clubs and whose parents or legal guardians received clarification regarding the study's procedures. Guidelines concerning research involving human subjects were complied with and consent was provided by the participants' parents or legal guardians; the Institutional Review Board at EEFE/USP approved the study (332007/ EEFE/04.04.2007-2006/32).

\section{Sample}

The sample was composed of 174 young male athletes aged between eight and 18 years old who took part in different sports (soccer: $n=146$; athletics: $\mathrm{n}=8$; indoor soccer: $\mathrm{n}=19$ and judo: $\mathrm{n}=1$ ).

\section{Inclusion/exclusion criteria}

Medical exams were performed to ensure the individuals were healthy, had no amputated limbs, took no medications that influenced on their metabolism, appetite or growth. Only those regularly training at least three times a week and having played competitively for at least one year were included. 


\section{Measurement protocol}

Each participant was assessed in a laboratory setting in the morning after a night of rest. Data were collected in a single session and the same examiner performed all measurements, before which, the individuals were invited to fully empty their bladders. Total body scanning was performed with DXA of the individuals wearing shorts and shirts, which was followed by anthropometric measures performed according to the recommendations found in the literature ${ }^{19,20}$.

\section{Establishment of Appendicular Lean Soft Tissue (ALST)}

The estimation of ALST using DXA (Scanner DPX-NT, GE Medical, Software Lunar DPX enCORE 2007 v. 11.40.004, Madison, WI) was performed considering the sum of the LST of the upper and lower limbs. The images of limbs were isolated from the trunk and head (ROIs) using software-generated standard cut-outs, which were manually adjusted when necessary. Specific anatomic markers were used to define the lower limbs: LST that extends from the traced and perpendicular line to the axis of the femoral neck and angled with the pelvic flap to the tips of the phalanges. For the upper limbs, the anatomic marker was LST that extends from the center of the arm to the tips of the phalanges, following the procedures of the manufacturer's manual.

\section{Chronological Age and Anthropometric Measures}

Age was considered the whole number nearest to the individual's chronological age measured in years based on the decimal values of the year of birth.

The anthropometric measures necessary to estimate ALST based on the models proposed by Quiterio et al. ${ }^{2}$ included body mass (BM) in $\mathrm{kg}$ and height $(\mathrm{H})$ in $\mathrm{cm}$, which were measured using a digital scale (Filizola, PL 200, Campo Grande, MS, Brazil) and a wall-fixed stadiometer (Sanny Medical Professional-ES2020, São Paulo, SP, Brazil) with $0.1 \mathrm{~kg}$ and $0.1 \mathrm{~cm}$ accuracy, respectively. Three skinfold measurements $(\mathrm{SKF})$ in $\mathrm{mm}$ : the thigh $\left(\mathrm{SKF}_{\text {Thigh }}\right)$, triceps $\left(\mathrm{SKF}_{\text {Trices }}\right)$ and calf $\left(\mathrm{SKF}_{\text {Calf }}\right)$ were measured with a Lange skinfold caliper (Beta Technology, Cambridge, Maryland) with $1 \mathrm{~mm}$ accuracy. Three perimeters $(\mathrm{P})$ in $\mathrm{cm}$ : thigh $\left(\mathrm{P}_{\text {Thigh }}\right)$, arm $\left(\mathrm{P}_{\text {Arm }}\right)$ and calf $\left(\mathrm{P}_{\text {Calf }}\right)$ were measured using an inelastic and inextensible two-meter long metal tape measure (Sanny Medical, Starrett SN-4010, São Paulo, SP, Brazil) with $0.1 \mathrm{~cm}$ accuracy.

\section{Measures accuracy}

The Absolute Technical Error of Measurement (TEM) and Relative Technical Error of Measurement (\%TEM) were computed to ensure accurate intra-observer measurements. In the days subsequent to data collection, the measurements were replicated in 13 individuals, always within tolerance intervals ${ }^{20}$, as previously described ${ }^{8}$.

\section{Estimates of Appendicular Lean Soft Tissue (ALST)}

The predictive models used for young male athletes (Body weight and height model and Corrected muscle girth model) proposed by Quiterio et $\mathrm{al}^{2}$, used to predict ALST, called here model 1 and 2, are: 


$$
\begin{aligned}
& \mathrm{ALST}_{\text {mod1 }}[\mathrm{kg}]=-20.39+(0.199 * \mathrm{BM}[\mathrm{kg}])+\left(3.29^{*} \operatorname{sex}\left[\mathrm{o}^{\wedge}=1 ; \uparrow=0\right]\right)+\left(14.2^{*} \mathrm{H}[\mathrm{m}]\right)+ \\
& \left(0.19^{*}\right. \text { Age[years]) }
\end{aligned}
$$

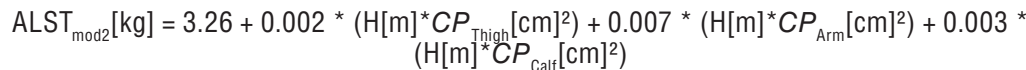

Where: $\mathrm{BM}=$ body mass; $\mathrm{H}=$ height; $C P=$ corrected muscle perimeters; $C P_{\text {Thigh }}=\mathrm{P}_{\text {Thigh }}[\mathrm{cm}]-$ $\left(\pi^{\star} \mathrm{SKF}_{\text {Thigh }}[\mathrm{cm}]\right) ; C P_{\text {Arm }}=\mathrm{P}_{\text {Arm }}[\mathrm{cm}]-\left(\pi^{\star} \mathrm{SKF}_{\text {Triceps }}[\mathrm{cm}]\right) ; C P_{\text {Calf }}=\mathrm{P}_{\text {Calf }}[\mathrm{cm}]-\left(\pi^{\star} S \mathrm{SK}_{\text {Calf }}[\mathrm{cm}]\right) ; \mathrm{P}=$ perimeters; SKF=skinfold; $\pi=3.1416$.

\section{Maturity}

Participant maturity considered pubic hair development according to Tanner's self-assessment method $^{13}$.

\section{Statistical analysis}

Mean, standard deviation, minimum and maximum values were used to describe the sample. The coefficient of determination $\left(\mathrm{r}^{2}\right)$, agreement according to a Bland-Altman ${ }^{21}$ plot were analyzed together with bias (the mean of differences between predicted and actual values) and the concordance correlation coefficient $\left(\rho_{c}\right)^{22}$ to determine the validity of anthropometric models in predicting ALST ${ }_{\text {DXA. }}$ Strength of concordance of $\rho_{\mathrm{c}}$ was classified ${ }^{23}$ as: poor $(<0.90)$, moderate (0.90-0.95), substantial (0.95-0.99), or almost perfect $(>0.99)$. Association between the mean and differences between predicted and actual values were verified. Any proposal of new anthropometric models, if necessary, would consider stepwise multiple linear regression, considering reduced multicolinearity $(\mathrm{VIF}<5)^{24}$ and validation using PRESS statistics (the sum of the squares of residuals) ${ }^{25}$. Statistical analyses were performed using SPSS v. 20 (Chicago, IL), plots and $\rho_{\mathrm{c}}$ in the MedCalc ${ }^{\oplus} 2015$ (v. 15.2); PRESS statistics in Minitab ${ }^{\oplus}$ (v. 17.3.1), all of which considered a level of significance established at $\alpha=0.05$.

\section{RESULTS}

The descriptive analysis, absolute and relative TEM of all the study's variables are presented in Table 1 . The \%TEMs were within the expected tolerance interval ${ }^{20}$, both for the anthropometric variables ( $0.11 \%$ to $\left.3.39 \%\right)$ and body composition ( $0.01 \%$ to $1.42 \%)$.

Most individuals were classified Pubertal ( $\mathrm{n}=128 ; 73.6 \%)$ when compared to Pre-Pubertal ( $n=26 ; 14.9 \%)$ and Post-Pubertal ( $n=20 ; 11.5 \%)$. Maturity was not, however, determinant in proposing models.

In the estimation of the variability of values measured by DXA, the Portuguese models (ALST $\mathrm{Aod}_{\min }$ and $\mathrm{ALST}_{\bmod 2}$ ) explained approximately $96.4 \%$ and 95.9\% $\left(\mathrm{r}^{2}\right)$, respectively, of the variability of the ALST $\mathrm{DXA}_{\text {A }}$ of Brazilian athletes.

The results for concordance (Bland-Altman) portray the mean differences between actual and predicted values (Figure 1): ALST $_{\text {mod1 } 1}$ slightly underestimated ALST $_{\text {DXA }}$ (a bias of $-0.7 \pm 1.5 \mathrm{~kg}$ ). Similarly, ALST mod2 $_{2}$ estimations underestimated ALST $_{\text {DXA }}$, however with greater magnitude (a bias of $-2.3 \pm 1.9 \mathrm{~kg}$ ). 
Table 1. Descriptive analysis of all the variables and Absolute (TEM) and Relative (\%TEM) Intraobserver Technical Error of Measurement.

\begin{tabular}{|c|c|c|c|c|c|c|}
\hline Variables & Mean & $\begin{array}{l}\text { Standard } \\
\text { Deviation }\end{array}$ & Minimum & Maximum & TEM & $\%$ TEM \\
\hline Chronological age (years) & 13.5 & 2.8 & 7.9 & 18.4 & - & - \\
\hline Sexual maturity (Tanner stages) & 3.0 & 1.3 & 1.0 & 5.0 & - & - \\
\hline Body Mass (BM) [kg] & 48.6 & 14.7 & 22.8 & 80.4 & 0.27 & 0.29 \\
\hline Height $(H)[m]$ & 1.6 & 0.2 & 1.2 & 1.9 & 0.17 & 0.11 \\
\hline $\mathrm{BMI}\left(\mathrm{kg} / \mathrm{m}^{2}\right)$ & 18.6 & 2.6 & 13.4 & 25.1 & - & - \\
\hline \multicolumn{7}{|l|}{ Skinfolds (SKF) [mm] } \\
\hline Triceps $\left(\mathrm{SKF}_{\text {Triceps }}\right)$ & 10.5 & 4.1 & 4.0 & 26.0 & 0.12 & 1.09 \\
\hline Thigh $\left(\mathrm{SKF}_{\text {Thigh }}\right)$ & 15.5 & 6.2 & 5.0 & 35.0 & 0.63 & 3.39 \\
\hline Calf $\left(\mathrm{SKF}_{\text {Calf }}\right)$ & 11.0 & 4.2 & 3.5 & 25.0 & 0.23 & 1.28 \\
\hline \multicolumn{7}{|l|}{ Perimeters $(\mathrm{P})[\mathrm{cm}]$} \\
\hline $\operatorname{Arm}\left(\mathrm{P}_{\text {Arm }}\right)$ & 21.5 & 3.2 & 15.3 & 28.4 & 0.31 & 1.35 \\
\hline Medial thigh $\left(\mathrm{P}_{\text {Thigh }}\right)$ & 43.8 & 6.4 & 27.5 & 58.0 & 0.70 & 1.47 \\
\hline Medial Calf $\left(\mathrm{P}_{\text {Calf }}\right)$ & 30.9 & 3.9 & 22.2 & 40.7 & 0.37 & 1.17 \\
\hline \multicolumn{7}{|c|}{ Corrected muscle perimeters (CP) [cm] } \\
\hline $\operatorname{Arm}\left(C P_{\text {Arm }}\right)$ & 18.2 & 3.3 & 11.9 & 26.2 & - & - \\
\hline Thigh $\left(C P_{\text {Thigh }}\right)$ & 39.5 & 6.7 & 23.4 & 54.0 & - & - \\
\hline Calf $\left(C P_{\text {Calf }}\right)$ & 27.5 & 3.9 & 18.5 & 34.5 & - & - \\
\hline \multicolumn{7}{|l|}{ DXA } \\
\hline Bone Mineral Content (kg) & 2.1 & 0.8 & 0.9 & 3.6 & 0.01 & 0.03 \\
\hline Fat Mass (kg) & 6.7 & 3.7 & 1.5 & 21.1 & 0.22 & 1.42 \\
\hline $\operatorname{ASLT}_{\mathrm{DXA}}(\mathrm{kg})$ & 18.5 & 6.6 & 6.9 & 30.5 & 0.03 & 0.14 \\
\hline $\mathrm{ASLT}_{\text {mod1 }}(\mathrm{kg})$ & 17.8 & 5.7 & 6.6 & 29.5 & - & - \\
\hline $\mathrm{ASLT}_{\bmod 2}(\mathrm{~kg})$ & 16.2 & 5.1 & 8.1 & 28.5 & - & - \\
\hline
\end{tabular}

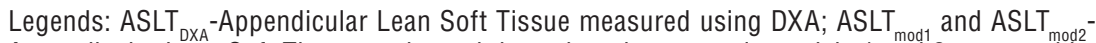
Appendicular Lean Soft Tissue, estimated through anthropometric models 1 and 2 proposed by Quiterio et al. ${ }^{2}$.

The limits of agreement (Bland-Altman), considering an interval of 95\% for both $\mathrm{ASLT}_{\bmod 1}$ and $\mathrm{ASLT}_{\bmod 2}$ (Figure 1), ranged between -2.1 and 3.6 and between -1.5 and $6.1 \mathrm{~kg}$, respectively. The Portuguese models $\mathrm{ASLT}_{\bmod 1}$ and $\mathrm{ASLT}_{\bmod 2}$ were more accurate when ALST values were low (below $18 \mathrm{~kg}$ and $11 \mathrm{~kg}$, respectively). The regression line concerning differences indicates a tendency of underestimation, as ALST values increased (Figures 1a and b).

The strength of concordance between predicted and actual values was substantial ( $\rho_{c}=0.966$; CI 95\%: 0.957 to 0.974$)$ for ALST $_{\text {mod1 }}$, but poor for ASLT $_{\bmod 2}\left(\rho_{c}=0.878\right.$; CI 95\%: 0.851 to 0.900$)$. A moderate association was also found $(r=0.593 ; \mathrm{p}<0.001)$ between the difference and mean of methods for $\mathrm{ASLT}_{\bmod 1}$ and $\mathrm{ASLT}_{\mathrm{DXA}_{\mathrm{A}}}$. Association between the difference and mean of the methods for ASLT $_{\bmod 2}$ and ASLT $_{\text {DXA }}$ was even greater $(r=0.798 ; p<0.001)$.

Therefore, the validation of ASLT $_{\bmod 2}$ failed because it presents important bias, decreased $\rho_{c}$ with significant association between difference and mean. Hence, new anthropometric models were proposed to predict ASLT $_{\text {DXA }}$, called ASLT mod3 $_{1}$, ASLT $_{\bmod 4}$ and ASLT $_{\text {mod5 }}$ (Table 2), based on the same anthropometric variables used in the Portuguese models. 


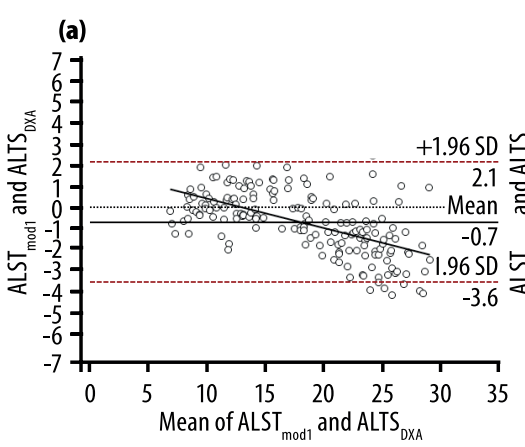

(d)

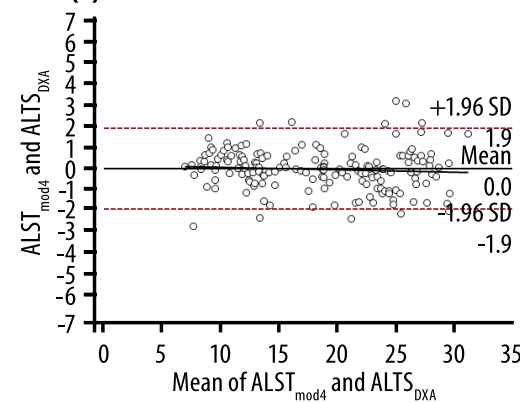

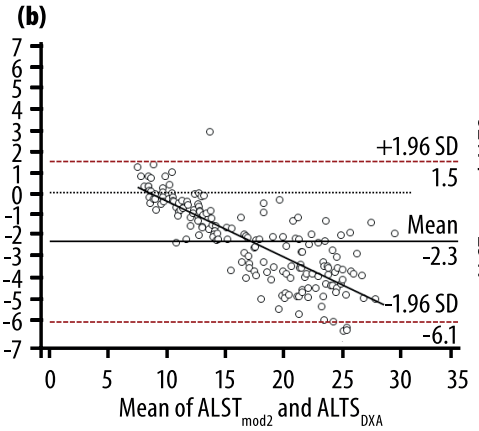

(e)

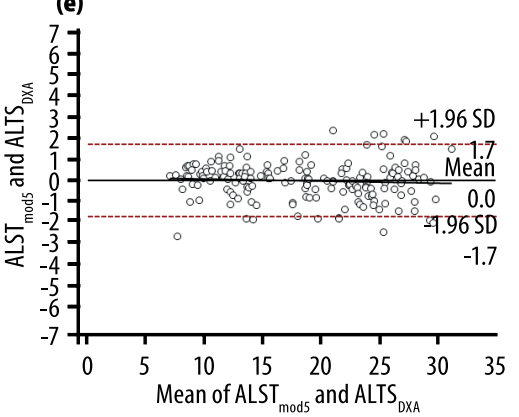

Figure 1. Bland-Altman plot and level of concordance between measurements of ALST in Kg using DXA (ALSTDXA) and values estimated by anthropometric predictive models developed by Quiterio et al.2: 1 (ASLT mod1 $\left._{1}\right)$-letter "a"; 2 (ASLT mod2 $_{2}$ )-letter "b"; and new proposed models: 3 ( ASLT $\left._{\text {mod } 3}\right)$-letter "c"; 4 (ASLT $T_{\text {mod4 } 4}$ )-letter "d" and 5 (ASLT mod $5_{5}$ )-letter "

Table 2. New models to predict Appendicular lean soft tissue (ALST $T_{\bmod 3}, A \mathrm{LST}_{\bmod 4}$ and $\mathrm{ALST}_{\bmod 5}$ ) of Brazilian young athletes.

\begin{tabular}{|c|c|c|c|c|c|c|c|}
\hline \multirow{2}{*}{ Models } & \multicolumn{3}{|c|}{ Independent variables } & \multirow{2}{*}{$\beta$} & \multirow{2}{*}{$\begin{array}{l}r^{2} \text { ad- } \\
\text { justed }\end{array}$} & \multirow{2}{*}{ SEE $(k g)$} & \multirow{2}{*}{ VIF } \\
\hline & $\mathrm{BM}$ & $\mathrm{SKF}_{\text {Triceps }}$ & $\mathrm{SKF}_{\text {Thigh }}$ & & & & \\
\hline $\mathrm{ALST}_{\bmod 3}$ & $0.433 \pm 0.09^{*}$ & & & $-2.553 \pm 0.441$ & 0.935 & 1.6831 & 1.000 \\
\hline $\mathrm{ALST}_{\bmod 4}$ & $0.429 \pm 0.01^{*}$ & $-0.337 \pm 0.02^{\star}$ & & $1.233 \pm 0.330$ & 0.978 & 0.9823 & 1.003 \\
\hline $\mathrm{ALST}_{\text {mod5 }}$ & $0.427 \pm 0.01^{*}$ & $-0.197 \pm 0.03^{*}$ & $-0.115 \pm 0.02^{*}$ & $1.620 \pm 0.305$ & 0.982 & 0.8897 & 2.850 \\
\hline
\end{tabular}

Legend: $\mathrm{r}^{2}$-coeficient of determination; SEE-standard error of estimate; VIF-Variance Inflation Factor; BM-Body Mass (kg); SKF- Skinfold $(\mathrm{mm}) ;{ }^{*}-p<0.001$.

The same statistical criteria previously used were applied to compare the new models with the actual measures $\left(\mathrm{r}^{2}\right.$, concordance, $\rho_{\mathrm{c}}$, association between mean and differences). All models presented high $r^{2}$ (Table 2), no bias or polarization of the mean (Figures 1c, $1 \mathrm{~d}$ and $1 \mathrm{e}$ ), and obtained substantial $\left(\rho_{\mathrm{cmod} 3}=0.967 ; \rho_{\mathrm{cmod} 4}=989\right)$ and almost perfect concordance strength $\left(\rho_{\text {cmods }}=0,991\right)$; and there was no association between means and differences of the methods ( $\mathrm{p}>0.05)$.

The models tested with PRESS statistics presented values close to the ideal values necessary for validation PRESS $_{\bmod 3}=499.84$; PRESS $_{\bmod 4}=173.57$ and PRESS $\left.{ }_{\bmod 5}=144.27\right)$, with $\mathrm{r}^{2}{ }_{\text {PRESS }}$ close to 1 $\left(r_{\text {PRESSmod } 3}^{2}=0.934 ; r_{\text {PRESSmod4 }}^{2}=0.977\right.$ and $\left.r_{\text {PRESSmod } 5}^{2}=0.981\right)$, and decreased $\mathrm{SEE}_{\text {PRESS }}(\mathrm{kg})\left(\mathrm{SEE}_{\text {PRESSmod3 }}=1.695\right)$ or close to zero $\left(\mathrm{SEE}_{\text {PRESSmod4 }}=0.999\right.$ and $\left.\mathrm{SEE}_{\mathrm{PRESSmod} 5}=0.911\right)$.

\section{DISCUSSION}

Only one of the anthropometric models designed by Quiterio et al. ${ }^{2}$ to 
predict ALST was validated in a sample of young athletes $\left(\right.$ ASLT $\left._{\text {mod1 }}\right)$. It presented high $\mathrm{r}^{2}$, small limits of agreement and its estimates strongly agreed with actual values ( $\mathrm{ALST}_{\mathrm{DXA}}$ ). Nonetheless, the estimates of the two models were prone to error when the individuals presented higher ALST values. Even though model 1 was valid, it presented polarization of the mean, underestimating ALST by approximately $1 \mathrm{~kg}$. The newly proposed models were validated by the PRESS method combining the leave-and-out system with adjusted measures (prediction error) to obtain a more accurate estimation of the models' predictive performance ${ }^{8}$. The new models presented greater agreement even for higher ALST and also performed well in all the criteria considered in the Portuguese models $\left(\mathrm{r}^{2}\right.$, concordance, bias, $\rho_{c}$, association between mean and differences of methods).

To the best of our knowledge, the models proposed by Quiterio et $\mathrm{al}^{2}$ are the only ones in the literature to estimate ALST (of the upper and lower limbs, concomitantly) of young athletes using anthropometric measures. Other studies proposed anthropometric models to predict ALST, however, involved few students of both sexes (20 boys and 19 girls) who did not practice vigorous exercise $e^{1}$. In some cases, they only estimate the ALST of the lower limbs of male school-age athletes ${ }^{26}$. Previous studies ${ }^{1}$ committed conceptual errors in the nomenclature of the variable measured by DXA, which was considered "Total Skeletal Muscle Mass", at level IV of human body composition (Organ-tissue level)3. Note that DXA performs measurements only at level II (Molecular level). The ALST estimates achieved with the Portuguese models in this study present $r^{2}$ values (0.96 and 0.95) higher than those found in the Portuguese study (0.91 and 0.93 ) in the same models 1 and 2, respectively. In the original study, however, the estimates of the model did not present bias toward error when the highest values of ALST were analyzed, as shown by the Bland-Altman plot. Remarkable differences found for some variables between the Portuguese subjects and those addressed in this study may have contributed to inaccuracy of the models estimating higher ALST (Figure $1 \mathrm{a}$ and $1 \mathrm{~b}$ ). On average, the athletes from the Portuguese study were classified lower on the Tanner scale $(1.7 \pm 0.7$ vs. $3.0 \pm 1.3)$, but they presented higher ALST ( $23.1 \pm 6.4$ vs. $18.5 \pm 6.6 \mathrm{~kg})$, Fat mass $(10.5 \pm 7.0$ vs. $6.7 \pm 3.7 \mathrm{~kg}), \mathrm{BMI}(21.5 \pm 2.84$ vs. $18.6 \pm 2.6), \mathrm{BM}(64.5 \pm 15.8$ vs. $48.6 \pm 14.7$ $\mathrm{kg})$, and height $(1.72 \pm 0.15$ vs. $1.60 \pm 0.20 \mathrm{~m})$. The usual anthropometric differences between Brazilian and Portuguese ${ }^{18}$ young individuals partly explain the population differences, suggesting ethnic specificity of models predicting body composition.

A limiting factor that may have led to greater inaccuracy in the Portuguese models involves the equipment used in this study (Scanner DPX-NT, GE Medical), which is different from the equipment used in the original study (DXA QDR-4500; Hologic, Walthman, MA). Body composition measurement may differ between brand ${ }^{27,28,29}$, though such differences have not been confirmed when specific comparisons are performed between ALST measured using different DXA equipment ${ }^{30}$. 


\section{CONCLUSION}

Only model 1 proposed by Quiterio et al. ${ }^{2}$ satisfactorily met validity criteria to estimate the ALST of young Brazilian athletes. The accuracy of estimates of the two Portuguese models, however, depended on the magnitude of ALST values. The newly proposed models complied with all validation criteria, presenting highly accurate estimates: $\mathrm{r}_{\text {PRESS }}^{2}(0.93$ to 0.98), low $\mathrm{SEE}_{\text {PRESS }}(0.91$ to $1.70 \mathrm{~kg}$ ) and satisfactory concordance regarding the ALST of young Brazilian athletes, regardless of the magnitude of the values. Nonetheless, before adopting models intended to predict the body composition of young individuals, one has to consider population differences that should be considered specifically.

\section{Acknowledgment}

We would like to thank the Interunit Doctoral Program in Nursing of the School of Nursing of Ribeirão Preto of the University of São Paulo (EERP-USP) and the Nutrition Course of the University of Ribeirão Preto (UNAERP) for financial support for the translation of this article. This research was supported by Coordination for the improvement of higher education personnel program (CAPES, Brazil).

\section{REFERENCES}

1. Poortmans JR, Boisseau N, Moraine J-J, Moreno-Reyes R, Goldman S. Estimation of total-body skeletal muscle mass in children and adolescents. Med Sci Sports Exerc 2005;37(2):316-22.

2. Quiterio AL, Carnero EA, Silva AM, Bright BC, Sardinha LB. Anthropometric models to predict appendicular lean soft tissue in adolescent athletes. Med Sci Sports Exerc 2009;41(4):828-36.

3. Wang Z-M, Pierson R, Heymsfield SB. The five-level model: a new approach to organizing body-composition research. Am J Clin Nutr 1992;56(1):19-28.

4. Kim J, Shen W, Gallagher D, Jones A, Wang Z, Wang J, et al. Total-body skeletal muscle mass: estimation by dual-energy X-ray absorptiometry in children and adolescents. Am J Clin Nutr 2006;84(5):1014-20.

5. Heymsfield SB, Adamek M, Gonzalez MC, Jia G, Thomas DM. Assessing skeletal muscle mass: historical overview and state of the art. J Cachexia Sarcopenia Muscle 2014;5(1):9-18.

6. Mitsiopoulos N, Baumgartner RN, Heymsfield SB, Lyons W, Gallagher D, Ross R. Cadaver validation of skeletal muscle measurement by magnetic resonance imaging and computerized tomography. J Appl Physiol 1998;85(1):115-22.

7. Lee RC, Wang Z, Heo M, Ross R, Janssen I, Heymsfield SB. Total-body skeletal muscle mass: development and cross-validation of anthropometric prediction models. Am J Clin Nutr 2000;72(3):796-803.

8. Machado D, Oikawa S, Barbanti V. The Multicomponent Anthropometric Model for Assessing Body Composition in a Male Pediatric Population: A Simultaneous Prediction of Fat Mass, Bone Mineral Content, and Lean Soft Tissue. J Obes 2013;2013:8.

9. Heymsfield S. Human body composition. Champaign: Human kinetics; 2005.

10. Heymsfield SB, Smith R, Aulet M, Bensen B, Lichtman S, Wang J, et al. Appendicular skeletal muscle mass: measurement by dual-photon absorptiometry. Am J Clin Nutr 1990;52(2):214-8. 
11. Wang ZM, Visser M, Ma R, Baumgartner RN, Kotler D, Gallagher D, et al. Skeletal muscle mass: evaluation of neutron activation and dual-energy X-ray absorptiometry methods. J Appl Physiol 1996;80(3):824-31.

12. Kim J, Wang Z, Heymsfield SB, Baumgartner RN, Gallagher D. Total-body skeletal muscle mass: estimation by a new dual-energy X-ray absorptiometry method. Am J Clin Nutr 2002;76(2):378-83.

13. Tanner J. Growth at Adolescence. Oxford: Blackwell Scientific Publications; 1962.

14. Martin AD, Spenst LF, Drinkwater DT, Clarys JP. Anthropometric estimation of muscle mass in men. Med Sci Sports Exerc 1990;22(5):729-33.

15. Doupe MB, Martin AD, Searle MS, Kriellaars DJ, Giesbrecht GG. A new formula for population-based estimation of whole body muscle mass in males. Can J Appl Physiol 1997;22(6):598-608.

16. Gobbo L, Ritti-Dias R, Avelar A, Silva A, Coelho-e-Silva M, Cyrino E. Changes in skeletal muscle mass assessed by anthropometric equations after resistance training. Int J Sports Med 2013;34(1):28-33.

17. Gobbo LA, Cyrino ES, Petroski ÉL, Cardoso JR, Carvalho FO, Romanzini $\mathrm{M}$, et al. Validation of anthropometric equations for the estimation of muscular mass by dual energy $\mathrm{x}$-ray absorptiometry in male college students. Rev Bras Med Esporte 2008;14(4):376-80.

18. Madureira AS, Sobral F. Estudo comparativo de valores antropometricos entre escolares brasileiros e portugueses. Rev Bras Cineantropom Desempenho Hum 1999;1(1):53-9.

19. Lohman T, Roche A, Martorell R. Anthropometric standardization reference manual. Champaign: Human Kinetics; 1988.

20. Norton K, Olds T, Albernaz NMFd. Antropométrica: um livro sobre medidas corporais para o esporte e cursos da área de saúde. Porto Alegre: ArtMed; 2005.

21. Bland JM, Altman DG. Statistical methods for assessing agreement between two methods of clinical measurement. Lancet 1986;1(8476):307-10.

22. Lin LI. A concordance correlation coefficient to evaluate reproducibility. Biometrics 1989;45(1):255-68.

23. McBride G. A proposal for strength-of-agreement criteria for Lin's concordance correlation coefficient. NIWA Client Report: HAM 2005-062.

24. Myers R. Classical and modern regression with applications. Boston: PWS and Kent Publishing Company. Inc; 1990.

25. Holiday DB, Ballard JE, Mckeown BC. PRESS-related statistics: regression tools for cross-validation and case diagnostics. Med Sci Sports Exerc 1995;27(4):612-20.

26. Valente-dos-Santos J, Coelho-e-Silva MJ, Machado-Rodrigues AM, ElferinkGemser MT, Malina RM, Petroski EL, et al. Prediction equation for lower limbs lean soft tissue in circumpubertal boys using anthropometry and biological maturation. PloS One 2014;9(9):1-9.

27. Modlesky CM, Lewis RD, Yetman KA, Rose B, Rosskopf LB, Snow TK, et al. Comparison of body composition and bone mineral measurements from two DXA instruments in young men. Am J Clin Nutr 1996;64(5):669-76.

28. Pritchard J, Nowson C, Strauss B, Carlson J, Kaymakci B, Wark J. Evaluation of dual energy X-ray absorptiometry as a method of measurement of body fat. Eur J Clin Nutr 1993;47(3):216-28.

29. Diessel E, Fuerst T, Njeh C, Tylavsky F, Cauley J, Dockrell M, et al. Evaluation of a new body composition phantom for quality control and cross-calibration of DXA devices. J Appl Physiol 2000;89(2):599-605.

30. Ioannidou E, Padilla J, Wang J, Heymsfield SB, Thornton JC, Horlick M, et al. Pencil-beam versus fan-beam dual-energy X-ray absorptiometry comparisons across four systems: appendicular lean soft tissue. Acta Diabetol 2003;40 (Suppl 1):S83-5.
CORRESPONDING AUTHOR

Dalmo Roberto Lopes Machado Av. Bandeirantes, 3900, Monte Alegre - 14040-907, Ribeirão Preto, SP, Brazil.

Email: dalmo@usp.br 